\title{
Tuoreita avauksia graduntekijöiltä
}

\author{
Ansiokkaista opinnäytetöistä palkittiin Yuan Wang \\ Joensuusta ja Liisa Nyblom Tampereelta.
}

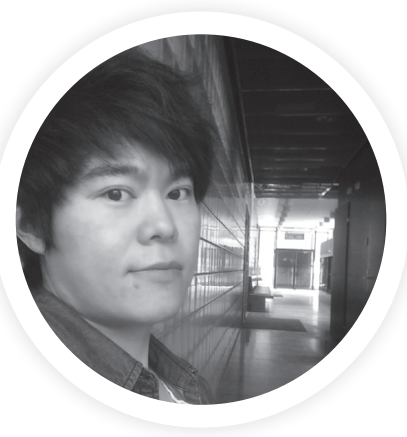

Yuan Wang jatkaa väitöskirjatutkijana Itä-Suomen yliopistossa.

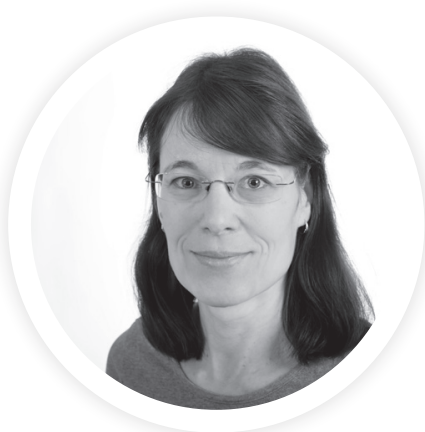

Liisa Nyblom keskittyy jatko-opinnoissaan poliittisten tekstien analyysiin.
YUAN WANG vertaili pro gradussaan Joensuun yliopiston ja Itä-Suomen yliopiston strategioita kriittisen diskurssianalyysin keinoin, historiallisella otteella. Työllään hän tekee näkyväksi yliopiston identiteettimuutoksen paikallisia arvoja ja yhteistyötä korostavasta maakuntayliopistosta kilpailua korostavaksi kansainväliseksi toimijaksi. Tutkimus tuo esiin tapausyliopiston markkinoitumiskehitystä kansallisessa ja eurooppalaisessa kehyksessä.

Opinnäyte "Once Upon a Reform: Marketization of Higher Education and the Identity Transition of a Finnish University after the Reform" osoittaa tekijän laajaa perehtyneisyyttä alan kansainväliseen kirjallisuuteen ja kykyä itsenäiseen tutkimustyöhön. Wang valmistelee Itä-Suomen yliopistoon väitöskirjaa Suomen Akatemian rahoittamassa akateemisen yrittäjyyden konsortiohankkeessa.
LIISA NYBLOM tutki Tampereen yliopistoon tekemässään pro gradussa koulutuspolitiikan linjauksia. Opinnäytteen nimi on "Osaamiseen perustuva kasvu - elinikäinen oppiminen ja aikuiskoulutus Kataisen ja Sipilän hallitusohjelmissa". Hänellä on rohkeutta tarttua vaativaan tutkimushaasteeseen ja kykyä saada esiin mielenkiintoisia tuloksia. Nyblom osoittaa, että keskeisistä politiikkateksteistä ovat kadonneet tai kaventuneet linjaukset, joilla turvataan laaja-alaista elinikäistä oppimista, kasvatuksen ja aikuiskoulutuspolitiikan edellytyksiä sekä aikuisväestön toisia mahdollisuuksia. Tarvitaan uudenlaista aikuiskoulutuspoliittista keskustelua.

Johdonmukainen, selkeä ja hyvin kirjoitettu opinnäyte vakuuttaa tekijän tutkijapotentiaalista ja on tärkeä lisä aikuiskasvatuksen teoriakehittelyyn. 